\title{
DETERMINATION OF NANOSCALE PARTICLES IN THE AIR OF WORKING ZONE AT THE METALLURGICAL PRODUCTION
}

\author{
T.S. Ulanova, M.V. Antipyeva, M.I. Zabirova, M.V. Volkova
}

FBSI "Federal Scientific Center for M edical and Preventive Health Risk Management Technologies", Russian Federation, Perm, 82, M onastyrskaya St., 614045

The results of studies of the air of working zone at the metallurgical production on the example of Avisma OJSC (Berezniki, the Perm Territory) for the content of nanoscale particles are specified. The maximum nanoparticles concentration in the range of $13523-28609 \mathrm{mln} . / \mathrm{m} 3$ is determined at the working place of the titanium production smelter with the maximum size of particles of 10-15 nm. At the working place in the administrative building (reference working place) the maximum concentration is determined within the range of $524-1000 \mathrm{mln} . / \mathrm{m3}$; the maximum size of nanoparticles is $20 \mathrm{~nm}$. It was established that the number concentration of nanoparticles at the reference working places (administration of Avisma OJSC) is significantly lower than at the working places of main production processes. The presented studies can be used as the additional factors in the assessment of labor conditions and occupational risk during the manufacture and use of materials containing nanoparticles as well as the production processes with the nanoparticles formation.

Key words: nanoparticles (<100 nm), number concentration, nanoparticle size distribution.

Currently, one of the key directions of the global technical progress development is the works on the creation of nanotechnologies and perspective nanomaterials. With the development of nanomaterials there are a lot of materials containing the nanoscale particles $(<100 \mathrm{~nm})$. Now, the volume of production manufacturing of nanomaterials in the developed countries is several thousand tons per year [2].

The aggregate of scientific data on nanomaterials allows for supposing that they can be potentially toxic for human. Studying the occurring potential risks at the contacts of human and other biological systems with nanomaterials is an urgent and important task. The implementation of nanotechnologies and nanomaterials requires the assessment of all the possible risks associated with their use.

The nanoteachnologies as any new teachnologies have not only the evident advantages but also the potential hazard of harmful impact on human and natural ecosystems. The analysis of a large number of scientific studies demonstrated that the nanoparticles have higher toxicity than normal mircoparticles, are able to penetrate in the unchanged form through the cellular barriers, as well as through the blood-brain barrier to the central nervous system, circulate and accumulate in the organs and tissues causing more expressed pathological and morphological affections of internal organs (for examle, formation of granulomas in lungs, liver cirrhosis, glomerulonephrosis), as well as, having the long-term half-period, are extremely heavily removed from the body [3-5].

The toxicity of nanoparticles is determined by their form and sizes. The target organs for nanoparticles can be the lungs, liver, kidney, brain, intestinal tract, and the dependence of target organs from the route of intake is traced. When exposed to nanoparticles it is possible to observe the development of oxidative stress, inhalation/transdeermal assimilation (accumulation and digestion), asthma, chronic obstructive lung disease (COLD), malignant neoplasms (lung cancer), neurodegenerative diseases, cardiovascular system and heart function disorders, cell genom disorder (DNA replication) [2,3].

In this context, especially urgent is the assessment of labot conditions and occupational risk during the manufacture and use of materials containing the nanoparticles, as well as production

(C) Ulanova T.S., Antipyeva M.V., Zabirova M.I., Volkova M.V., 2015

Ulanova Tatyana Sergeevna - Doctor of Biological Sciences, head of the Department of chemical and analytical research methods (e-mail: ulanova@ fcrisk.ru; tel. +7(342) 233-10-34).

Antipyeva Marina Vladimirovna - Candidate of biological science, Senior research assistant of the laboratory of methods for analysis of nanomaterials and finely-divided particles (e-mail: girmar@mail.ru; tel. +7 (342) 233-10-34).

Zabirova Marina Igorevna - research engineer of the laboratory of methods for analysis of nanomaterials and finelydivided particles (e-mail: 79824541888@yandex.ru; tel. +7 (342) 233-10-34).

Volkova Marina Valeryevna - chemist of the laboratory of methods for analysis of nanomaterials and finely-divided particles (e-mail: mari_703@mail.ru; tel. 8 (342) 233-10-34). 
processes with formation of nanoparticles. The production processes with the highest risk of harmful impact of the nanoscale aerosols include the electric arc welding and cutting of metals, pyrometallurgical metal purification processes [2].

The purpose of work is to study the content of nanoscale parcticles in the air of working zone of metallurgical plant on the example of Avisma OJSC (Berezniki, the Perm Territory).

Materials and methods. When examining the air of working zone the determination of nanoparticles by sizes and measuring of their number concentration was performed using the diffusion aerosol spectrometer DAS 2702 (Russia) [1].

Study of the air of working zone was conducted at the working places of metallurgical production of Avisma OJSC which is a branch of VSMPO-Avisma Corporation OJSC and located in Berezniki of thePerm Territory.

The working places of metallurgical production were assessed based on the examination of the working place of titanium production smelter at the performance of high-temperature production processes for titanium slug smelting: dressing, iron tapping, titanium slug tapping, closing of tap-hole fireproof plug of electric arc furnace.

The administrative unit off Avisma OJSC separated from the production process is examined as the comparison working place.

The air of working zone was studied for the distribution by sizes and determination of number concentration of nanoparticles.

Results and their discussion. The performed studies are shown in fig. 1-3. Fig. 1 shows the dis- tribution of suspended particles by sizes: the axis $x$ represents the values of the ranges of sizes of particles in nanometers; axis $y$ reflects the number concentration of particles in the million of particles per $1 \mathrm{~m}^{3}$. The maximum nanoparticles concentration corresponds to the range from 15024 to 26481 mln. particles per $1 \mathrm{~m}^{3}$, the size of particles $10-65$ $\mathrm{nm}$ with maximum number concentration in the range of 30-35 $\mathrm{nm}$. During dressing the air of working zone at the working place of smelter is occupied by particles with sizes in the range of 5$20 \mathrm{~nm}$, the number concentration is represented by the interval 13523-28609 mln. particles per $1 \mathrm{~m}^{3}$ (maximum in the range of 10-15 nm).

The comparison working place examination results are shown in frig. 2, 3 and in table.

According to the results of study of the air of working zone at the territory of administration (comparison working place) performed at three points it can be concluded that the maximum concentration of particles is within the range of sizes $15-55 \mathrm{~nm}$, the number concentration 527-1000 mln. particles per $1 \mathrm{~m}^{3}$ (with maximum belonging to the particles of size $\sim 20 \mathrm{~nm}$ ).

Therefore, the performed measurements of distribution and number concentration of nanoparticles in the air of working zone of the main production processes and administrative building of Avisma OJSC (metallurgical productions) allows for making the conclusion that the number concentration of nanoparticles at the comparison working places (administration of Avisma OJSC) is significantly lower than at the working places of the main production processes.

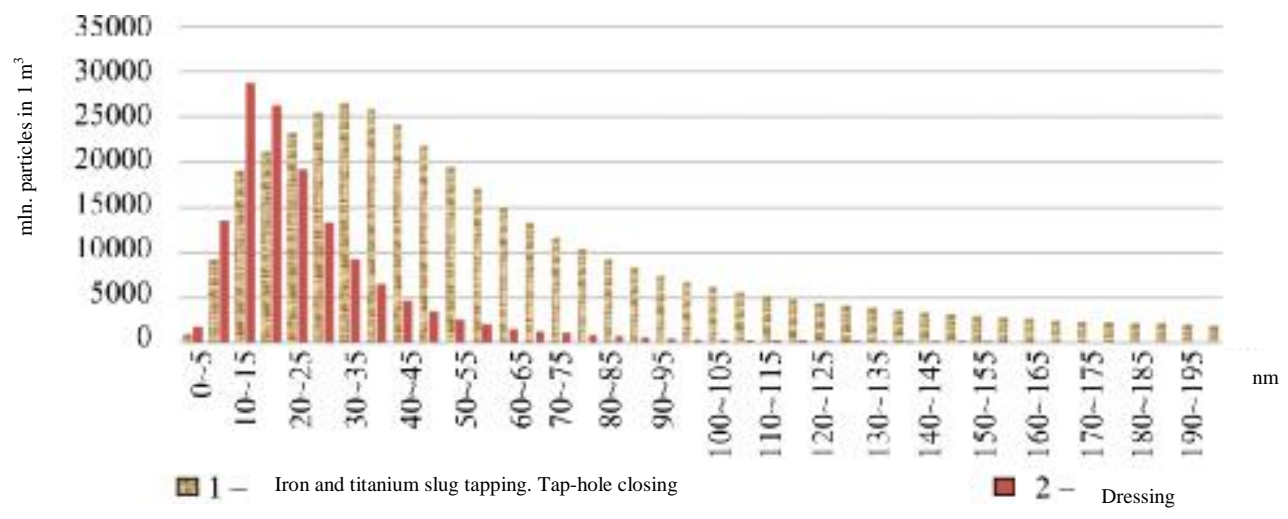

Fig. 1. Distribution by sizes and number concentration of nanoparticles in the air of working zone at Avisma OJSC 


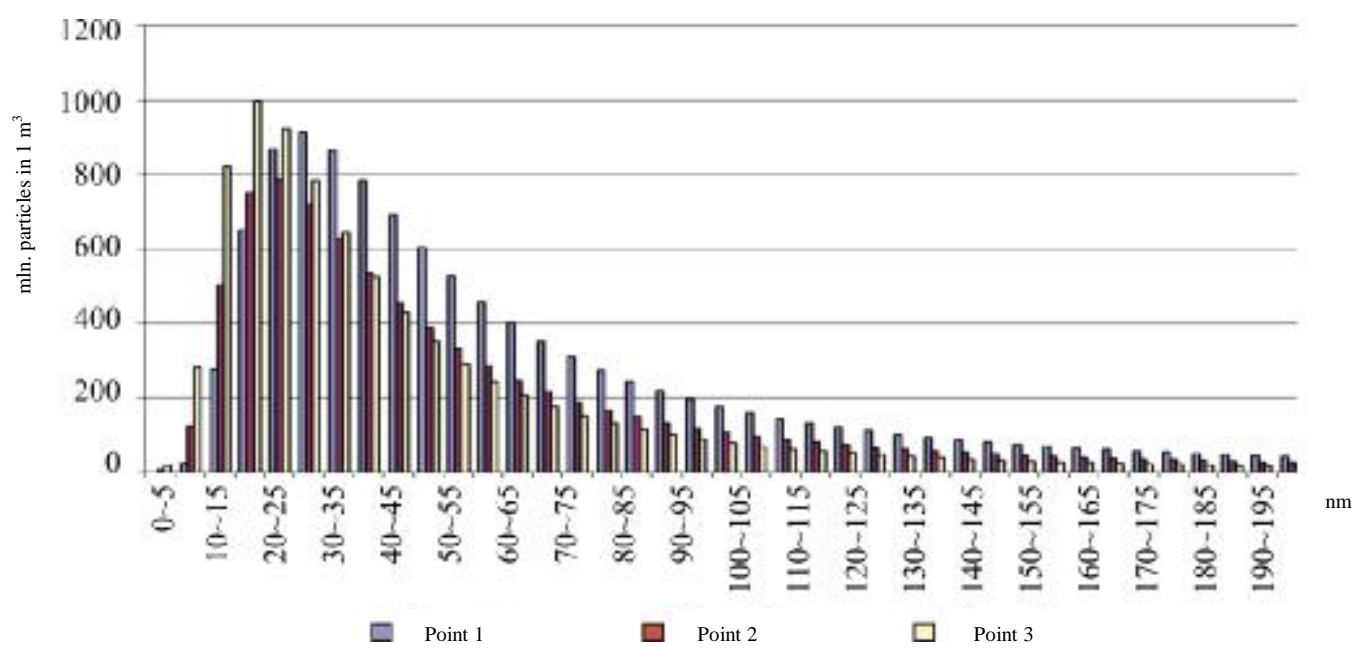

Fig. 2. Characterization of nanoparticles in the air of working zone of the administrative unit of Avisma OJSC

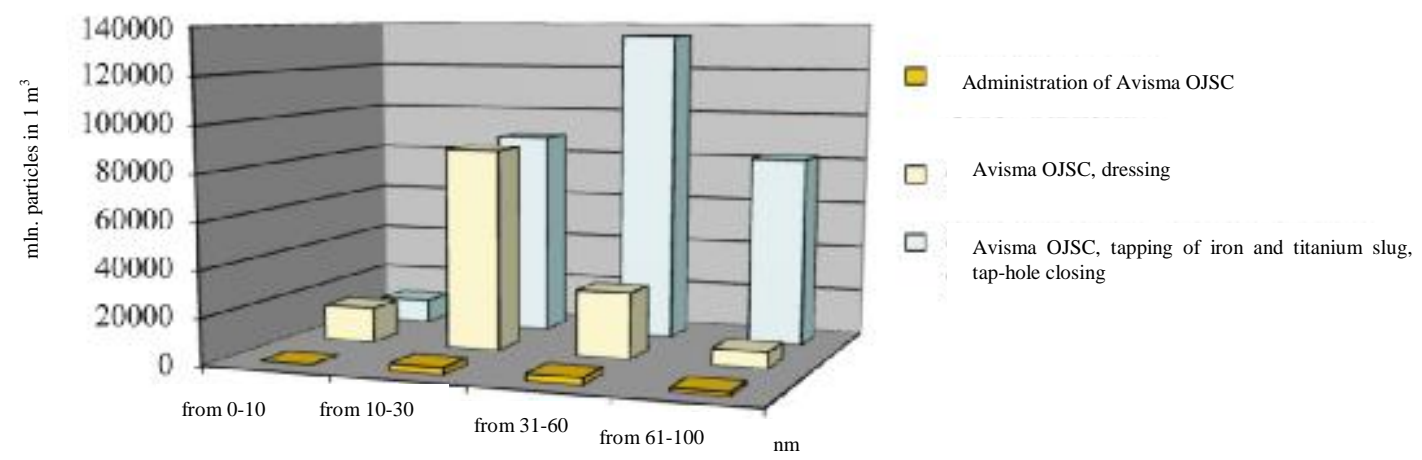

Fig. 3. Comparison of the distribution of nanoparticles in the air of working zone at the comparison and observation working places

Concentration of particles in the air of working zone at Avisma OJSC

\begin{tabular}{|l|c|c|}
\hline \multicolumn{1}{|c|}{ Name of examined place } & $\begin{array}{c}\text { Maximum concen- } \\
\text { tration of particles, } \\
\mathrm{mln} / \mathrm{m}^{3}\end{array}$ & $\begin{array}{c}\text { Size range of particles } \\
\text { with maximum concentra- } \\
\text { tion, nm }\end{array}$ \\
\hline Administration & $527-1000$ & $\sim 20$ \\
\hline $\begin{array}{l}\text { Shop No. 37, working place of the titanium production smelter, dress- } \\
\text { ing }\end{array}$ & $13523-28609$ & $10-15$ \\
\hline $\begin{array}{l}\text { Shop No. 37, working place of the titanium production smelter, taping } \\
\text { of iron and titanium slug, tap-hole closing }\end{array}$ & 15024 до 26481 & $30-35$ \\
\hline
\end{tabular}

The working places of the titanium production smelter at the stage of dressing, tapping of iron and titanium slug, tap-hole closing differ under the range of maximum concentration of nanoparticles and the size range of particles with maximum concentration.
The data obtained during studies can be used as the additional information when assessing the labor conditions and occupational risk during the production and use of materials containing the nanoparticles as well as the production processes with formation of nanoparticles. 


\section{References}

1. Diffuzionnyj ajerozol'nyj spektrometr. Model' 2702. Rukovodstvo po jekspluatacii 66334978.002.000RJe [Diffusion aerosol spectrometer. Model 2702. Operation manual 66334978.002.000RE]. OOO «AjeroNanoTeh» g. Moskva, 2013. Available at: http://ru.aeronanotechnology.com/diffuzionnyy aerozolnyyspektrometr.

2. Onishhenko G.G. Organizacija nadzora za oborotom nanomaterialov, predstavljajushhih potencial'nuju opasnost' dlja zdorov'ja cheloveka [Organization of supervision over the turnover of nanomaterials posing potential danger for the health of humans]. Gigiena i sanitarija, 2011, no 2, pp. 4-9.

3. Zajceva N.V., Zemljanova M.A., Zvezdin V.N., Saenko E.V. Toksikologo-gigienicheskaja ocenka bezopasnosti vodnoj suspenzii nanodispersnogo dioksida kremnija, sintezirovannogo metodom zhidkokristallicheskogo templantirovanija [Toxicological and hygienic assessment of safety of the aqueous suspension of nanodisperse silicon dioxide synthesized by the liquid-crystalline templating method]. Analiz riska zdorov'ju, 2013, no 1, pp. 65-72.

4. Chen Z., Meng H., Xing G. et al. Acute toxicological affects of copper nanoparticles in vivo. The journal of physical chemistry. Toxicology letters, 2006, no 163, pp. 109-120.

5. Chiu - Wing Lam, James John T, McCluskey R. et al. Pulmonary toxicity of single-wall carbon nanotubes in mice 7 and 90 days after intratracheal instillation. Toxicol. Science, 2003, no 77, pp. 126-134. 